\title{
Study of the Effect of Absorber Layer Thickness of CIGS Solar Cells with Different Band Gap Using SILVACO TCAD
}

\author{
Amina Maria Laoufi ${ }^{1}$, B. Dennai ${ }^{2}$, O. Kadi ${ }^{1}$, M. Fillali ${ }^{3}$ \\ 1 Smart Grid \& Renewable Energy (SGRE Lab), Tahri Mohamed University of Bechar, Bechar, Algeria \\ ${ }^{2}$ Laboratory for the Development of Renewable Energies and their Applications in Saharan areas (LDREAS), Tahri \\ Mohamed University of Bechar, Bechar, Algeria \\ ${ }^{3}$ Physics \& Semiconductor Devices Laboratory (LPDS) Tahri Mohamed University of Bechar, Bechar, Algeria
}

(Received 19 March 2021; revised manuscript received 04 August 2021; published online 20 August 2021)

\begin{abstract}
In this paper, we have simulated a copper indium gallium selenide (CIGS) thin-film solar cell using a physically based two-dimensional device simulator SILVACO Atlas. The simulation of electrical characteristics and quantum efficiency was under AM1.5 illumination and a temperature of $300 \mathrm{~K}$. In this work, we changed the band gap of $\mathrm{CuIn}_{x} \mathrm{Ga}_{1-x}$ Se to optimize the efficiency of the solar cell. We obtained it by varying the absorber layer thickness with different mole fractions $x$ that affects the efficiency of the solar cell. The simulation result shows that the maximum efficiency of $16.62 \%$ was achieved with a band gap of $1.67 \mathrm{eV}$ and a thickness of $3 \mu \mathrm{m}$, a short-circuit current density of $29.293 \mathrm{~mA} / \mathrm{cm}^{2}$, an open-circuit voltage of $1.29 \mathrm{~V}$, and a fill factor of $87.79 \%$. The obtained results show that the proposed design can be considered as a potential candidate for high performance photovoltaic applications.
\end{abstract}

Keywords: Solar cell, CIGS, Band gap, SILVACO, Thickness, Performance.

\section{INTRODUCTION}

As the population increased, the demand for electricity from photovoltaic modules increased at lower costs, so there is a need for novel light-absorbing materials that can promise comparable conversion efficiency at lower manufacturing costs than existing crystalline silicon [1]. Thin-film solar cells based on $\mathrm{Cu}$, In, Ga, Se comply with the performance of thin-film photovoltaic panel technologies. In recent decades, they are among the most frequently used because of their high efficiency and low cost, for this reason, they are so promising and widely used [2,3].

Quaternary semiconductors, especially $\mathrm{Cu}$ In Ge Se (CIGS), are attracting great attention as absorber materials [4]. The variable band gap is what makes CIGS a special characteristic, which can be optimized by varying the $\mathrm{Ga} /(\mathrm{In}+\mathrm{Ga})$ ratio to obtain different band gaps for different depths in the CIGS film [5].

In this paper, a physically based two-dimensional device simulator SILVACO Atlas [6] is used to simulate the absorber for a CIGS solar cell structure with different thickness. The simulated CdS/CIGS thin-film solar cell consists of a $\mathrm{ZnO}$ window/CdS buffer layer/CIGS absorber. Light enters the cell through the window and passes through the entire solar cell. Fig. 1 shows the schematic of the solar cell design studied in this work.

\section{THEORETICAL MODEL}

\subsection{The Concept of Template}

The simulator adopted in this paper is a physically based 2D/3D device simulator SILVACO TCAD (Technology Computer Aided Design). The simulation software is based on the finite element method. Various TCAD tools such as Athena and Atlas can be used, but in this work, we mainly used Atlas [6]. It predicts the electrical behavior of specified semiconductor structures

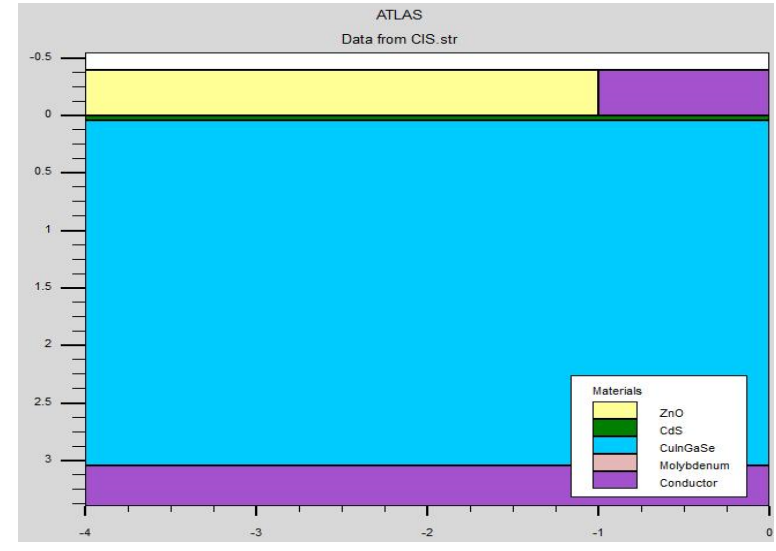

Fig. 1 -Schematic structure of the CIGS solar cell

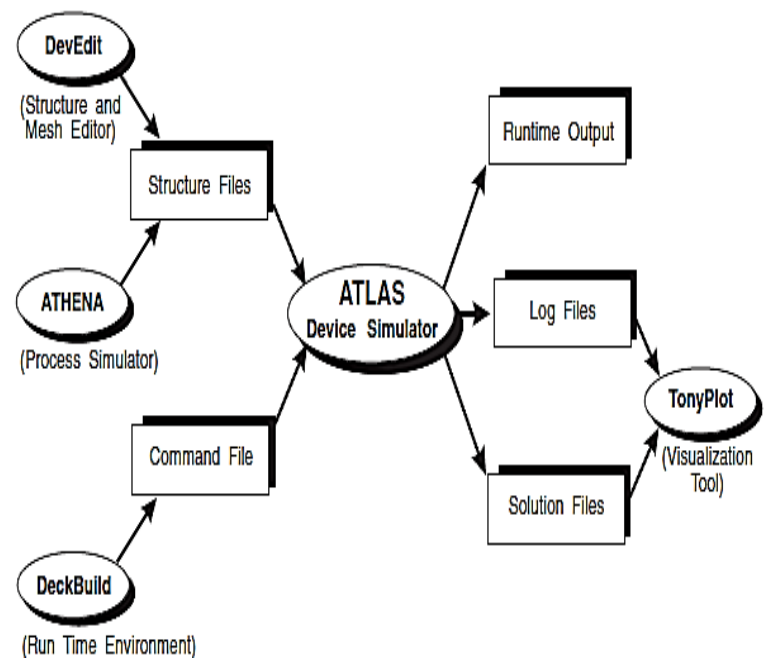

Fig. 2 -Atlas inputs and outputs [7]

and provides insight into the internal physical mechanisms associated with device operation [7]. 
For the simulation in ATLAS of a solar cell, script, information must be entered into Deck Build, and it is necessary to specify different parameters of the cell structure. The definition of the structure must also include the cornerstone of the simulation because it builds a network of the cell through its precise division and bsears the physical dimensions and thickness of the different layers that make up the cell. The importance of the cell network is that at the intersection of the network points (nodes) to enable the study of cell behaviour a set of differential equations must be solved in order to simulate the transport of cell vectors [8].

SILVACO Atlas can calculate solar cell characteristics such as conversion efficiency $(\eta)$, shortcircuit current density $\left(J_{s c}\right)$, open-circuit voltage $\left(V_{o c}\right)$, fill factor $(\mathrm{FF})$, and quantum efficiency $(\mathrm{QE})$.

\section{DESIGN AND SIMULATION}

In SILVACO Atlas software, we have to input the material properties of each layer in the cell structure via the Deckbuild interface.

To study the effect of changing the absorber layer thickness, we simultaneously varied the mole fraction to change the band gap of the absorber layer. We first fixed the thickness parameters, then alternately varied the mole fractions $(x=0,0.31,0.45,0.66,1)$ in order to analyze their influence on the characteristics of the CIGS solar cell with a solar cell surface area of $0.4 \mathrm{~cm}^{2}$.

For proper design of $\mathrm{CuIn}_{1-x} \mathrm{Ga}_{x} \mathrm{Se}_{2}$ based solar cell, we have to analyze the equation of the material main parameters, such as band gap, electron affinity, permittivity. An approximate expression for the band gap of $\mathrm{CuIn}_{1-x} \mathrm{Ga}_{x} \mathrm{Se}_{2}$ semiconductor alloys was used:

$$
E g(x)=1.011+0.664 x-0.249(1-x) .
$$

Here, $E_{g}$ ranges from 1.011 to $1.68 \mathrm{eV}$ for $x=0$ (CIS) and $x=1$ (CGS), respectively. The electron affinity of CIGS is expressed as given below:

$$
\chi(x)=-0.242 x^{2}-0.454 x+4.68 .
$$

The relative permittivity is written as

$$
\varepsilon(x)=15.1-5 x .
$$

In this work, all simulations were performed for the AM1.5 solar spectrum with $P=1000 \mathrm{~W} / \mathrm{cm}^{2}$ and at a temperature $T=300 \mathrm{~K}$ using an ideal single-diode model.

Table 1 shows a description of the parameters used in the simulation and the main parameters that are used in the study.

\section{SIMULATION RESULTS AND DISCUSSION}

Simulations were performed to compare different types of cell structure created by varying the thickness and mole fraction of CIGS absorber layers to find out the best structure for higher efficiency and more stable CIGS solar cells. The simulation results can be seen in Fig. 3, Fig. 4, Fig. 5, and Fig. 6. These figures show in detail the effect of the absorber layer, the thickness of which has increased from 1 to $3 \mu \mathrm{m}$, on cell parameters such as $V_{o c}, J_{s c}, \mathrm{FF}$ and $\eta$ from SILVACO simulation.
Table 1 - Parameters for simulation

\begin{tabular}{|l|c|c|c|}
\hline Parameters & N-ZnO & N-CdS & $\begin{array}{l}\text { P- } \\
\text { CIGS }\end{array}$ \\
\hline Thickness $(\mu \mathrm{m})$ & 0.4 & 0.05 & $/$ \\
\hline Relative permittivity $\varepsilon$ & 9 & 10 & 13.6 \\
\hline Band gap $(\mathrm{eV})$ & 3.3 & 2.48 & $/$ \\
\hline Electron affinity $(\mathrm{eV})$ & 4.5 & 4.18 & 4.58 \\
\hline Electron mobility $\left(\mathrm{cm}^{2} / \mathrm{Vs}\right)$ & 50 & 100 & 100 \\
\hline Hole mobility $\left(\mathrm{cm}^{2} / \mathrm{V}_{\mathrm{s}}\right)$ & 5 & 25 & 25 \\
\hline $\begin{array}{l}\text { Effective density of states in } \\
\text { the conduction band }(N c) \\
\left(\mathrm{cm}^{-3}\right)\end{array}$ & $2.2 \mathrm{e}^{18}$ & $2.41 \mathrm{e}^{18}$ & $2.2 \mathrm{e}^{18}$ \\
\hline $\begin{array}{l}\text { Effective density of states in } \\
\text { the valence band }\left(N_{V}\right)\left(\mathrm{cm}^{-3}\right)\end{array}$ & $1.8 \mathrm{e}^{19}$ & $2.57 \mathrm{e}^{19}$ & $1.8 \mathrm{e}^{19}$ \\
\hline Donor concentration $\left(\mathrm{cm}^{-3}\right)$ & $1 \mathrm{e}^{18}$ & $1 \mathrm{e}^{17}$ & 0 \\
\hline Acceptor concentration $\left(\mathrm{cm}^{-3}\right)$ & 0 & 0 & $8 \mathrm{e}^{16}$ \\
\hline
\end{tabular}

Since $I_{s c}$ is proportional to the area of the solar cell, to compare various solar cells, the short-circuit current density $J_{s c}=I_{s c} / A$ is often used, where $A$ represents the surface area of the cell. By applying a potential to the cell, the current decreases and the voltage develops as charge accumulates at the terminals. The resulting current can be considered as the sum of the shortcircuit current $I_{s c}$, originated from the photon absorption process. The current density is as follows [9]:

$$
J=J_{S C}-J_{0}\left(e^{\frac{q V}{T K_{B}}}-1\right)
$$

where $J_{0}$ is a constant, $q$ is the electron charge and $V$ is the applied voltage.

The open-circuit voltage $V_{o c}$ can be calculated by setting $J=0$ :

$$
V_{O C}=\frac{T K_{B}}{q} \ln \left(\frac{J_{S C}}{J_{0}}+1\right) .
$$

The maximum output power density of a solar cell is achieved somewhere between $V=0$ and $V=V_{o c}$ at a voltage $V_{m}$. The corresponding current density is called $J_{m}$, and thus the maximum power density is

$$
P m=J m * V m .
$$

So, the efficiency of a solar cell is defined as a ratio of the maximum electrical power density produced to the incident light power density:

$$
\eta=\frac{P_{\max }}{P_{\text {inc }}}=\frac{I_{\max } V_{\max }}{P_{\text {inc }}} .
$$

Fig. 3 shows the changes in the current density in terms of the mole fraction with different absorber layer thicknesses.

As we can see, with increasing mole fraction, the band gap increases, which leads to a decrease in the number of absorbed photons, and hence to a decrease in the current density.

Fig. 4 shows the changes in the open-circuit voltage in terms of the mole fraction with different absorber layer thicknesses.

As we can see, with increasing mole fraction, the band gap increases, and this leads to an increase in the number of absorbed photons, and, thus, the open circuit voltage increases. 


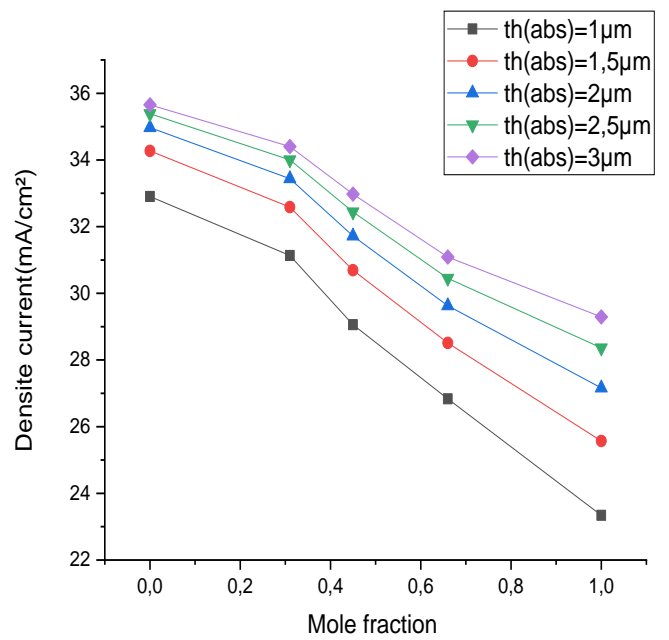

Fig. 3 - Variation of $J_{s c}$ on the absorber layer thickness for various mole fractions

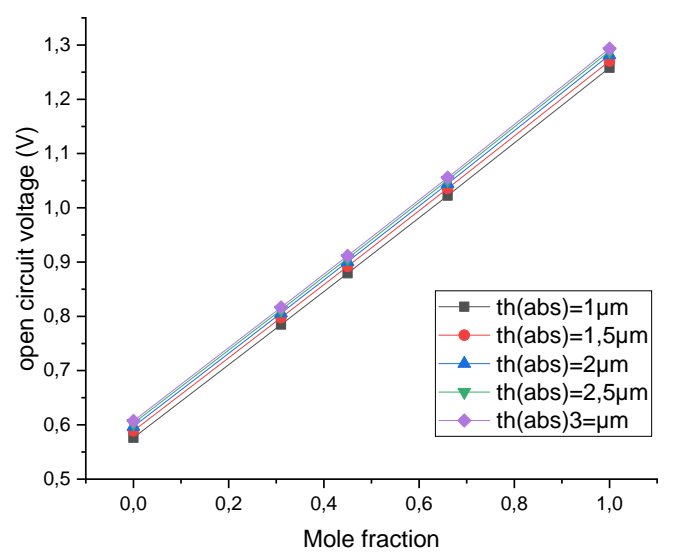

Fig. 4-Variation of $V_{o c}$ on the absorber layer thickness for various mole fractions

Fig. 5 shows the changes in the fill factor (FF) in terms of the mole fraction with different absorber layer thicknesses.

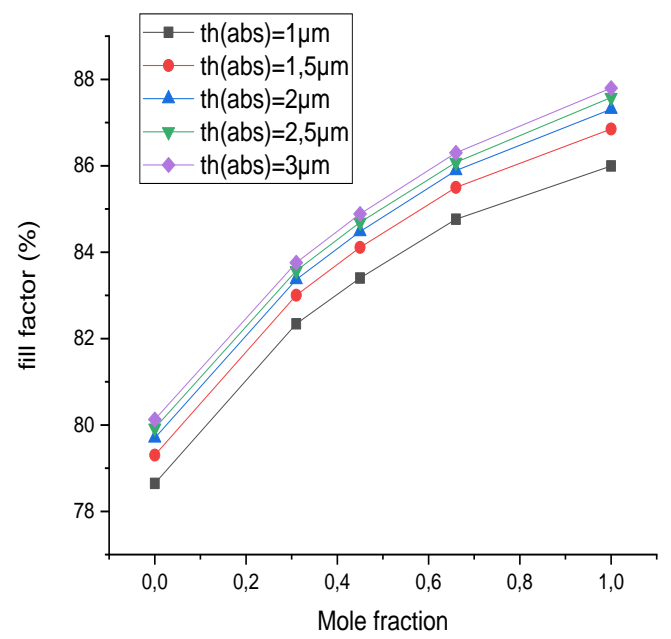

Fig. 5-Variation of FF on the absorber layer thickness for various mole fractions

An increase in the mole fraction leads to an increase in the fill factor.
Fig. 6 shows the changes in the efficiency $(\eta)$ of the CIGS solar cell in terms of the mole fraction with different absorber layer thicknesses.

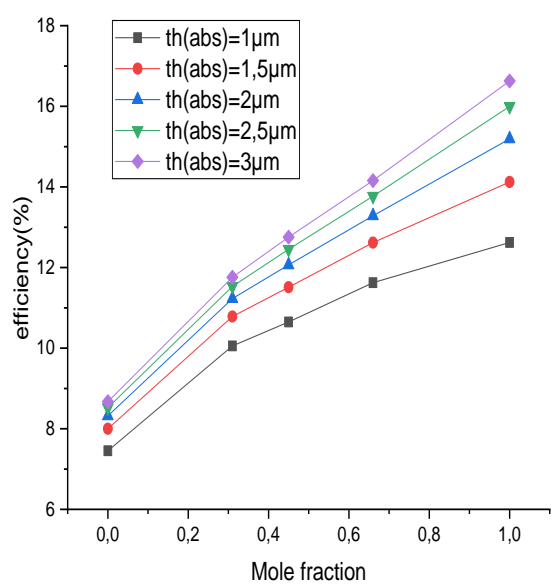

Fig. 6-Variation of $\eta$ on the absorber layer thickness for various mole fractions

An increase in the mole fraction leads to an increase in the efficiency due to an increase in voltage.

\section{RESULT OF OPTIMIZATION}

Based on the above results obtained by SILVACO TCAD software, we can determine the solar cell that has the best efficiency when the thickness is equal to $3 \mu \mathrm{m}$ and the mole fraction is 1 . The corresponding PV parameters such as open-circuit voltage $V_{o c}$, shortcircuit current density $J_{s c}$, fill factor FF and efficiency $\eta$ are all summarized in Table 2.

Table 2 - PV parameters of the optimized CIGS device

\begin{tabular}{|l|c|c|c|c|}
\hline & $V_{o c}(\mathrm{~V})$ & $J_{s c}\left(\mathrm{~mA} / \mathrm{cm}^{2}\right)$ & $\mathrm{FF} \mathrm{( \% )}$ & $\eta(\%)$ \\
\hline $\begin{array}{l}\text { Our simulated } \\
\text { results }\end{array}$ & 1.293 & 29.29 & 87.79 & 16.62 \\
\hline $\begin{array}{l}\text { Measurement } \\
\text { results [9] }\end{array}$ & 0.634 & 34.33 & 70.21 & 15.28 \\
\hline $\begin{array}{l}\text { Other } \\
\text { simulated } \\
\text { results [9] }\end{array}$ & 0.631 & 34.38 & 70.31 & 15.23 \\
\hline
\end{tabular}

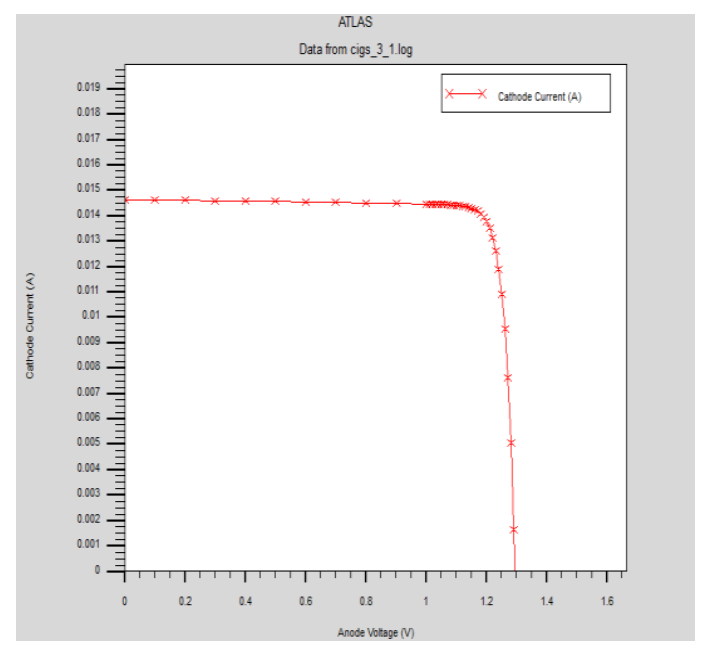

Fig. 7 -Current-voltage characteristics of the optimal CIGS solar cell 
The current-voltage characteristics generated by the CIGS solar cell optimized device under the AM1.5 spectrum and one sun are displayed in Fig. 7.

The power-voltage characteristics generated by the CIGS solar cell optimized device under the AM1.5 spectrum and one sun are displayed in Fig. 8.

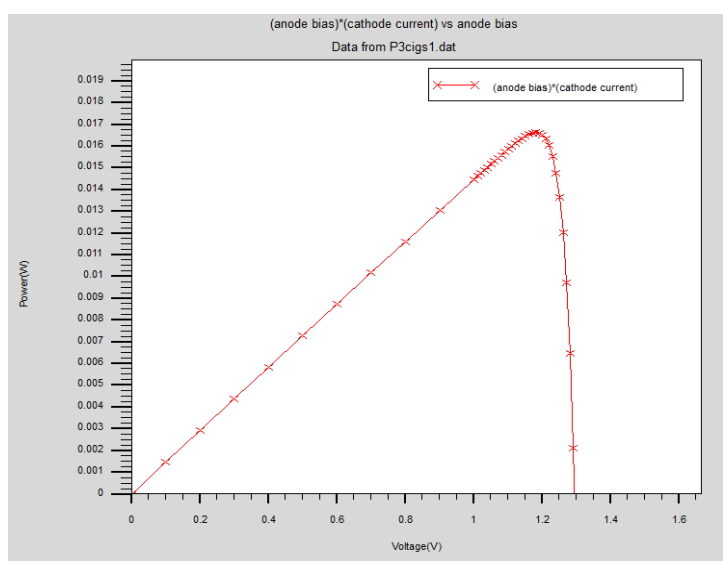

Fig. 8-Power-voltage characteristics of the optimal CIGS solar cell

The quantum efficiency (QE) of the optimal CIGS solar cell from SILVACO simulation is shown in Fig. 9. The cell with a thickness of $3 \mu \mathrm{m}$ maintains almost over $72 \%$ of $\mathrm{QE}$ in the entire visible spectrum, where the best conversion efficiency of the cell is confirmed.

\section{REFERENCES}

1. B. Zaidi, M. Zouagri, S. Merad, C. Shekhar, B. Hadjoudja, B. Chouial, Acta Phys. Pol. A 136 No 6, 988 (2019).

2. N. Mufti, T. Amrillah, A. Taufiq, Sunaryono, Aripriharta, M. Diantoro, Zulhadjri, H. Nur, Sol. Energy 207, 1146 (2020).

3. P. Jackson, D. Hariskos, R. Wuerz, O. Kiowski, A. Bauer, T.M. Friedlmeier, M. Powalla, phys. status solidi 9 No 1, 28 (2015)

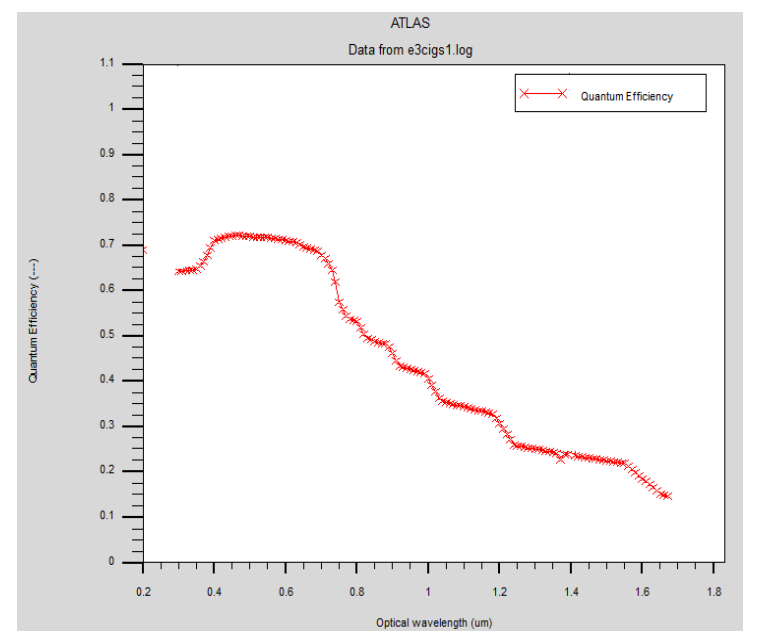

Fig. 9 - Quantum efficiency of the optimal CIGS solar cell

\section{CONCLUSIONS}

To optimize the solar cell performance, it is necessary to optimize parameters such as thickness, dosage, the solar cell structure, material quality, surface recombination rate (front and back), etc.

The results obtained show that the thickness of the absorber layer strongly influences the efficiency of the solar cell; and the thickness of the absorber layer equal to $3 \mu \mathrm{m}$ gives the best efficiency, since the thickness of the solar cell is an important parameter for absorption of photons. The CIGS solar cell with an absorber layer thickness of $3 \mu \mathrm{m}$ provides a photocurrent density of $29.293 \mathrm{~mA} / \mathrm{cm}^{2}$ and an efficiency of $16.62 \%$.

4. Y.C. Wang, H.P.D. Shieh, Appl. Phys. Lett. 105 No 7, 1 (2014).

5. M. Fillali, B. Dennai, J. Ovonic Res. 15 No 5, 279 (2019).

6. Silvaco Inc., "Atlas User's Manual," Silvaco Inc., No 408, 89 (2016)

7. E. Lt Col Davis, D. Arthur, Dr. Yoho, D. Keenan, Tech. Rep., 123 (2012).

8. B. Farhadi, M. Naseri, Superlattice Microst. 96, 104 (2016).

9. J. Park, M. Shin, Energies 11 No 7, 1785 (2018).

\title{
Вивчення впливу товщини шару поглинача сонячних елементів на основі CIGS з різною шириною забороненої зони за допомогою SILVACO TCAD
}

\author{
Amina Maria Laoufi ${ }^{1}$, B. Dennai², O. Kadi ${ }^{1}$, M. Fillali ${ }^{3}$
}

${ }^{1}$ Smart Grid \& Renewable Energy (SGRE Lab), Tahri Mohamed University of Bechar, Bechar, Algeria

${ }^{2}$ Laboratory for the Development of Renewable Energies and their Applications in Saharan areas (LDREAS), Tahri Mohamed University of Bechar, Bechar, Algeria

${ }^{3}$ Physics \& Semiconductor Devices Laboratory (LPDS) Tahri Mohamed University of Bechar, Bechar, Algeria

У роботі ми змоделювали тонкоплівковий сонячний елемент на основі міді, індію, галію та селеніду (CIGS) за допомогою симулятора SILVACO Atlas. Моделювання електричних характеристик та квантової ефективності проводилось при освітленні AM1,5 та температурі 300 К. У роботі ми змінили ширину забороненої зони $\mathrm{CuIn}_{x} \mathrm{Ga}_{1-x} \mathrm{Se}$, щоб оптимізувати ефективність сонячного елементу. Ми отримали його, варіюючи товщину шару поглинача з різними молярними частками $x$, які впливають на ефективність сонячного елементу. Результат моделювання показуе, що максимальна ефективність 16,62 \% була досягнута при ширині забороненої зони 1,67 еВ і товщині 3 мкм, густині 
струму короткого замикання $29,293 \mathrm{~mA} / \mathrm{cm}^{2}$, напрузі холостого ходу $1,29 \mathrm{~B}$ і коефіціента заповнення 87,79 \%. Отримані результати показують, що запропоновану конструкцію можна розглядати як потенційного кандидата для високоефективних фотоелектричних застосувань.

Ключові слова: Сонячний елемент, CIGS, Ширина забороненої зони, SILVACO, Товщина, Продуктивність. 